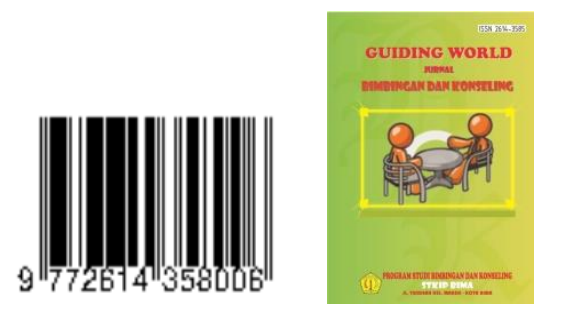

\title{
Efektivitas Model Experiential Learning Untuk Meningkatkan Keterampilan Mengelola Emosi Marah
}

\author{
Nurhayati, Faijin, Amiruddin, Sulistia Indah \\ Prodi Bimbingan dan Konseling, Sekolah Tinggi Keguruan Dan Ilmu Pendidikan (STKIP) Bima \\ Email: sophynurhayati@yahoo.co.id
}

\begin{abstract}
Abstrak
Rasa marah merupakan bagian dari emosi yang dimiliki oleh semua individu, dalam kadar tertentu hampir setiap individu pernah mengalaminya. Terkadang individu sulit untuk mengontrol emosi marah, hal itu tergantung dari keterampilan individu dalam mengelola emosi marah yang muncul, oleh karena itu, guru BK perlu memberikan latihan agar peserta didik memiliki keterampilan dalam mengelola emosi marah melalui teknik tertentu. Tujuan penelitian untuk mengetahui keefektifan model experiential learning untuk melatih keterampilan pengelolaan emosi marah. Rancangan penelitian ini menggunakan True Experimental Pre-test, Posttest Control Group Design. Populasi penelitian adalah peserta didik SMP Negeri 6 Kota Bima kelas VII. Subjek penelitian terjaring secara random sehingga diperoleh sejumlah 10 orang yang dibagi ke dalam kelompok eksperimen $(n=5)$ dan kelompok kontrol $(n=5)$. Instrumen lain yang digunakan adalah lembar penilaian diri, lembar tugas mengelola emosi marah dan pedoman observasi. Teknik statistik yang digunakan untuk menguji hipotesis adalah Two Independent Sample Test Mann Whitney untuk membandingkan perbedaan skor keterampilan pengelolaan emosi marah antara kelompok eksperimen dan kelompok kontrol. Hasil analisis menunjukkan bahwa nilai koefisien Z (2.207) dengan signifikansi sebesar 0.027 yang berarti 0.027 di bawah nilai probabilitas yaitu $(0.027<0.05)$. Berdasarkan hasil uji statistik tersebut dapat disimpulkan bahwa $\mathrm{HO}$ ditolak yang berarti ada perbedaan yang signifikan antara peserta didik yang diintervensi dengan model experiential learning dan peserta didik yang diintervensi dengan bimbingan secara umum, sehingga model experiential learning efektif untuk meningkatkan keterampilan pengelolaan emosi marah peserta didik SMP. Hasil pelatihan menunjukan bahwa model experiential learning bisa untuk mengajarkan keterampilan mengelola emosi marah peserta didik SMP.
\end{abstract}

Kata Kunci : Bimbingan Kelompok, Percaya Diri, Keluarga Kurang Harmonis.

\section{PENDAHULUAN}

Masa SMP adalah masa perkembangan yang kritis karena suasana emosi terutama keterampilan dalam menata dan mengelola emosi usia SMP masih sangat minim, sehingga kemampuan mengontrol diri, dan mengarahkan diri terutama emosi marah sangat sangat rendah. Disiplin dasar atau disiplin diri akan membantu individu untuk secara sadar berpikir 


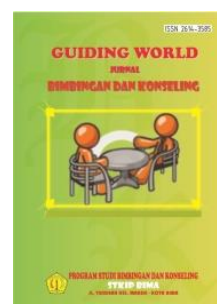

E-ISSN: 2614-3585

dan bersikap sesuai nilai-nilai dan aturan sosial yang berlaku, yakni kesadaran untuk mengatur, mengontrol, dan mengarahkan diri sendiri secara mandiri agar sesuai dengan nilai/aturan agama, nilai/aturan diri sendiri, dan sesuai dengan nilai/aturan sosial di sekolah. Disiplin diri menurut Bryant (2008) "kesadaran untuk mengarahkan diri (self-direction), dan mengatur diri (self- regulation)".Terkait itu menurut Shochib (1998) disiplin diri adalah memiliki "keteraturan diri berdasarkan: (1) nilai agama, (2) nilai budaya,(3) aturan-aturan sosial (nilai pergaulan), (4) pandangan hidup, (5) sikap hidup yang bermakna bagi diri, masyarakat, Bangsa dan Negara. Karena disiplin diri akan membantu individu memiliki keterampilan "kontrol diri-menahan diri dan kemandirian-kebebasan diridalam mengambil keputusan dalam bertindak atau bereaksi (Nurhayati, 2014).

Peserta didik yang memiliki pengalaman mengatur, mengontrol, dan mengarahkan diri akan memiliki pengalaman dan keterampilan dalam mngelola diri termasuk mengelola emosi marah, pengelolaan emosi merupakan sebuah keterampilan yang bisa di pelajari dan bisa di ajarkan. Menurut Goleman (1995) pengelola emosi sebagai bagian dari kecerdasan emosional bisa diperoleh dengan banyak belajar melalui pengalaman sendiri. Karena keterampilan mengelola emosi tidak bisa dicapai hanya dengan memberikan materi atau informasi melalui metode ceramah tetapi harus dengan praktik atau dilatihkan (Goleman, 1995).Hal ini bermakna pelatihan keterampilan mengelola emosi sangat penting untuk diajarkan kepada para peserta didik sebagai program pencegahan terhadap masalah yang terjadi pada remaja seperti: merokok, penyalahgunaan obat terlarang, kehamilan, putus sekolah, bullying dan tindakan kekerasan lain yang terjadi pada remaja.

Hasil studi awal pada peserta didik SMPN 6 Kota Bima menunjukan bahwa pertengkaran terjadi pada peserta didik karena sikap dan tindakan yang terlalu terbawa emosi marah sehingga terjadi perkelahian baik dalam kelompok kecil maupun dalam kelompok besar.Keadaan tersebut memicu terjadinya tawuran yang bahkan tidak terkendali, karena itu penting sekali peserta didik untuk memiliki keterampilan dalam mengelola emosi marah agar mampu mengatur, mengontrol, dan mengarahkan diri sendiri. Karena menurut Rogers 1959 (dalam Feist, J. \& Feist, G.J. 2006) manusia terlahir dengan membawa potensi kreativitas untuk memecahkan masalah, mengubah konsep diri dan mengarahkan diri sendiri termasuk memecahkan masalah kemarahan. Peran orang dewasa terutama konselor sekolah sangat penting untuk membantu peserta didik memiliki pengalaman dalam mengelola emosi marah.

Hasil wawancara dengan guru BK didapatkan data bahwa dalam melaksanakan pelayanan dasar bimbingan dan konseling guna mencapai aspek perkembangan kematangan emosi peserta didik menggunakan metode ceramah/nasehat, dan belum pernah melakukan pelatihan untuk meningkatkan keterampilan mengelola emosi peserta didik, karena tidak memiliki media berupa pedoaman/panduan yang mendukung pelaksanaan pelatihan untuk mengelola emosi marah peserta didik. Kondisi seperti ini, tentu saja tidak boleh dibiarkan apalagi peserta didik sebagai individu yang sedang berada dalam proses berkembang, yaitu berkembang kearah kematangan dan kemandirian, dan jika kerisis emosi terjadi pada peserta didik maka akan berdampak pada kekacauan emosi seperti bullying, putus sekolah, penyalahgunaan obat-obatan dan alkohol, kejahatan, resiko kehamilan, penyakit menular seksual, dan lebih parahnya bisa berdampak pada kematian.

Harus dipahami bahwa pelayanan bimbingan dan konseling di sekolah menengah merupakan seting yang paling subur bagi konselor, karena di jenjang itulah konselor dapat 


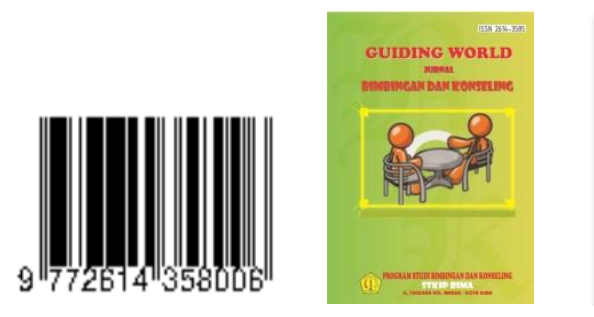

berperan secara maksimal dalam memfasilitasi konseli agar dapat mengaktualisasikan diri dan potensi yang dimilikinya secara optimal (ABKIN, 2008). Pada kenyataannya konselor sekolah belum memiliki wawasan keilmuan dan keterampilan yang memadai dalam melatih peserta didik untuk mengelola emosi marah, oleh sebab itu peneliti merasa perlu untuk merancang perangkat pelatihan keterampilan mengelola emosi dengan model experiential learning.

Jadi pelaksanaan model experiential learning untuk melatih keterampilan mengelola emosi marah akan mengikuti panduan hasil Tesis pengembangan Sony Gunawan, yang berbentuk buku panduan untuk konselor dan peserta didik yang berisi seperangkat kegiatan pelatihan keterampilan mengelola emosi dengan model experiential learning yang sistematis dan digunakan dalam layanan bimbingan di sekolah. Menurut Kolb (1984), experiential learning itu sendiri berisi tiga aspek yaitu:

1) Pengetahuan (konsep, fakta, informasi), 2) aktivitas (penerapan dalam kegiatan), dan

3) Refleksi (analisis dampak kegiatan terhadap perkembangan individu). Ketiga aspek di atas memberikan kontribusi penting untuk tercapainya tujuan belajar berbasis pengalaman.

Prosedur dan tahapan pelatihan keterampilan mengelola emosi marah, terdiri dari: 1) pembentukan kelompok, 2) pelatihan keterampilan mengelola emosi marah (kontrol diri, pengaturan diri, dan pengarahan diri), 3) Penutup. Siklus empat langkah experiential learning dalam proses belajar yang digunakan dalam penelitian ini yaitu:

1) concrete experience (emotions), 2) reflective observation (watching), 3) abstract conceptualization (thinking), dan 4) active experimentation (doing).

Keterampilan mengelola emosi marah adalah bentuk kemampuan menggunakan pikiran, nalar, dan perbuatan dalam menangani perasaan agar dapat terungkap dengan tepat atau selaras, sehingga tercapai keseimbangan dalam diri individu (Goleman,1995). Tujuan pelatihan keterampilan mengelola emosi adalah untuk keseimbangan emosi dan bukan menekan emosi, karena setiap emosi memiliki nilai dan makna tersendiri. Menjaga agar emosi yang merisaukan tetap terkendali merupakan kunci menuju kesejahtraan emosi. Emosi berlebihan yang meningkat dengan intensitas terlampau lama akan mengoyak kesetabilan (Goleman, 1995).

Masalah yang berhubungan dengan emosi tidak bisa dianggap biasa, selain itu juga perlu ada solusi jika emosi yang muncul secara berlebihan. Menurut Stephan (2012) "emosi yang tumpang tindih, dalam jangka pendek, pada perasaan eksistensial akan dicirikan oleh ketegangan, kelelahan, dan rasa gagal". Kecerdasan emosi menentukan potensi seseorang untuk mempelajari keterampilan-keterampilan praktis yang didasarkan pada lima unsur yaitu: 1) kesadaran diri (mengenali emosi sendiri), 2) pengaturan diri (mengelola emosi), 3) motivasi diri sendiri, 4) mengenali emosi orang lain (empati), dan 5) kecakapan dalam membina hubungan baik dengan orang lain (Goleman, 1995).

Mengelola emosi dapat dilakukan tergantung pada kemampuan untuk mengenali emosi diri, karena merupakan aspek yang paling mendasar pada keterampilan mengelola emosi. Keterampilan mengelola emosi dalam pelatihan yang akan dilakukan ini terdiri dari dua aspek yaitu: 1) mengenali emosi diri dan 2) mengekspresikan emosi secara wajar. Mengenali emosi diri sendiri merupakan suatu kemampuan untuk mengenali perasaan sewaktu perasaan itu terjadi. Hal ini menyebabkan individu menyadari emosi yang sedang dialami, mengetahui 

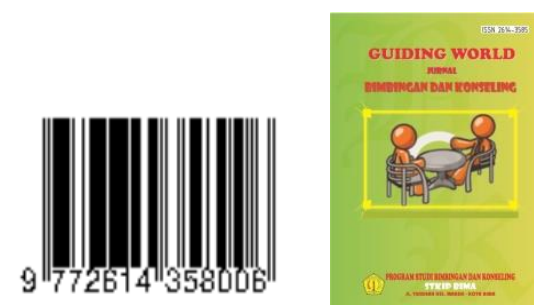

GUIDING WORLD JURNAL

BIMBINGAN DAN KONSELING

DOI: 1033627

Volume 03, Nomor 01

Mei 2020

E-ISSN: 2614-3585

penyebab emosi tersebut terjadi, memahami kuantitas, intensitas, dan durasi emosi yang sedang berlangsung. Seseorang akan lebih mudah memahami dan mengelola emosinya apabila telah mampu mengenali emosinya. Mengenali emosi sama dengan kesadaran diri mengenali perasaan sewaktu perasaan itu terjadi.

Menurut Mayer (Goleman, 1995) kesadaran diri adalah waspada terhadap suasana hati maupun pikiran tentang suasana hati, bila kurang waspada maka individu menjadi mudah larut dalam aliran emosi dan dikuasai emosi. Mengenali emosi diri memang belum menjamin penguasaan emosi, namun merupakan salah satu prasyarat penting untuk mengendalikan atau mengelola emosi sehingga individu mudah menguasai emosi (Goleman, 1995). Adapun menurut Goleman (1995), unsur-unsur mengenali emosi diri adalahsebagai berikut: 1) mengetahui emosi yang sedang dirasakan, dapat mengetahui alasan timbulnya emosi tersebut, 2) menyadari rantai emosi dengan tindakan (hubungan antara perasaanperasaannya dan apa yang sedang dipikirkan, dilakukan dan dikatakan), 3) mengenali bagaimana perasaan-perasaan itu mempengaruhi kinerja, kualitas pengalaman dalam hubungan mereka, dan 4) memiliki kesadaran penuntun terhadap nilai-nilai dari tujuan.

Mengetahui emosi yang sedang dirasakan, dan dapat mengetahui alasan timbulnya emosi. Terkadang emosi itu sulit untuk diketahui, mungkin pada saat merasa lelah, tidak bersemangat, hilang nafsu makan, sehingga tidak tahu bahwa sedang mengalami kesedihan. Atau pada saat merasa tekanan darah naik, hilang kendali, dan nafas tidak teratur sehingga tidak menyadari sedang merasakan emosi marah. Ketidakmampuan untuk mengetahui emosi membuat diri berada dalam kekuasaan emosi, artinya kehilangan atas perasaan yang pada gilirannya membuat kehilangan kendali atas diri sendiri.

Untuk menyadari dampak emosi terhadap perkataan dapat diketahui dengan mengenali pengekspresian emosi dalam verbal atau kata-kata yang diucapkan dalam keadaan emosi.Contohnya: kamu seharusnya malu pada diri sendiri. Kata 'malu' adalah emosi yang dapat menghancurkan psikologi anak dan sering kali memicu rasa bersalah yang sangat mendalam. Mengenali bagaimana perasaan-perasaan itu mempengaruhi kinerja, kualitas pengalaman dalam hubungan mereka.Untuk mengenal dan mengetahui emosi dapat dilakukan pula dengan cara mengamati kinerja seseorang sebagai akibat dari munculnya reaksi emosi yang terjadi pada diri. Adapun contoh damapak atau pengaruh emosi terhadap kinerja adalah: emosi marah biasanya cendrung menunjukkan tingkah laku yang agresif jika dilihat dari segi negatif dan emosi marah juga dapat meningkatkan keberanian dan kepercayaan diri jika dilihat dari segi positif (Fatimah, 2010).

Memiliki kesadaran penuntun terhadap nilai-nilai dari tujuan. Seseorang yang memiliki kesadaran emosi memiliki kemampuan untuk mengetahui emosi-emosi yang dirasakan, mengapa emosi berhubungan dengan pikirannya, mengakui bagaimana akibat perasaan itu terhadap tindakannya serta menjadi penuntun bagi kesadaran untuk mencapai tujuan (Mayer \& Cobb, 2000). Menurut Hein (2004) dan Mayer \& Salovey (2000), seseorang yang memiliki kesadaran emosi, maka ia mempunyai kesadaran emosi dan akan menunjukkan sikap, yaitu: a) memberi nama (label) perasaan diri daripada memberi nama situasi, b) membedakan antara pikiran-pikiran dan perasaan- perasan, c) bertanggungjawab terhadap perasan-perasan, d) menggunakan perasaan- perasaan untuk membuat keputusan, e) menunjukkan penghargaan terhadap perasaan orang lain, f) menguatkan perasaan bukan marah, g) mengakui perasaan orang lain, h) menerima nilai-nilai perasaan secara positif 


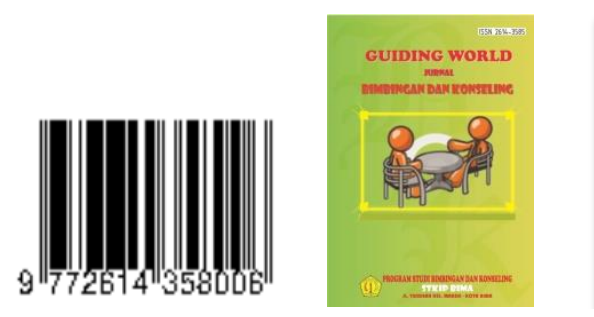

daripada negatif, i) tidak menasehati, memberi perintah, mengawasi, menggurui atau menghakimi perasaan orang lain, dan j) menghindari diri dari tidak menerima atau tidak menghargai perasaan orang lain.

Mengekspresikan emosi secara wajaradalah kemampuan individu untuk menampakkan perilaku berdasarkan perasaan yang terjadi pada dirinya secara wajar dan benar dengan cara-cara yang wajar pula. Emosi merupakan energi yang memberikan kekuatan untuk bertindak dan oleh sebab itu emosi membutuhkan saluran bagi energi sebagai jalan keluar, misalnya diekspresikan melalui perilaku. Emosi tidak pernah salah, tetapi emosi yang menjadi ekspresi suatu perasaan bisa salah (Ekman,2003). Contohnya: peserta didik yang takut dimarahi oleh guru karena tidak mengerjakan PR (Pekerjaan Rumah) lalu memilih untuk tidak pernah masuk sekolah.

\section{KERANGKA TEORITIS}

Keterampilan mengelola emosi marah adalah bentuk kemampuan menggunakan pikiran, nalar, dan perbuatan dalam menangani perasaan agar dapat terungkap dengan tepat atau selaras, sehingga tercapai keseimbangan dalam diri individu (Goleman, 1995). Tujuan pelatihan keterampilan mengelola emosi adalah untuk keseimbangan emosi dan bukan menekan emosi, karena setiap emosi memiliki nilai dan makna tersendiri. Menjaga agar emosi yang merisaukan tetap terkendali merupakan kunci menuju kesejahtraan emosi. Emosi berlebihan yang meningkat dengan intensitas terlampau lama akan mengoyak kesetabilan (Goleman, 1995).

Masalah yang berhubungan dengan emosi tidak bisa dianggap menurut Mayer (Goleman, 1995) kesadaran diri adalah waspada terhadap suasana hati maupun pikiran tentang suasana hati, bila kurang waspada maka individu menjadi mudah larut dalam aliran emosi dan dikuasai emosi. Mengenali emosi diri memang belum menjamin penguasaan emosi, namun merupakan salah satu prasyarat penting untuk mengendalikan atau mengelola emosi sehingga individu mudah menguasai emosi (Goleman, 1995). Adapun menurut Goleman (1995), unsurunsur mengenali emosi diri adalahsebagai berikut: 1) mengetahui emosi yang sedang dirasakan, dapat mengetahui alasan timbulnya emosi tersebut, 2) menyadari rantai emosi dengan tindakan (hubungan antara perasaan-perasaannya dan apa yang sedang dipikirkan, dilakukan dan dikatakan), 3) mengenali bagaimana perasaan-perasaan itu mempengaruhi kinerja, kualitas pengalaman dalam hubungan mereka, dan 4) memiliki kesadaran penuntun terhadap nilai-nilai dari tujuan. Menurut Stephan (2012) "emosi yang tumpang tindih, dalam jangka pendek, pada perasaan eksistensial akan dicirikan oleh ketegangan, kelelahan, dan rasa gagal". Kecerdasan emosi menentukan potensi seseorang untuk mempelajari keterampilanketerampilan praktis yang didasarkan pada lima unsur yaitu: 1) kesadaran diri (mengenali emosi sendiri), 2) pengaturan diri (mengelola emosi), 3) motivasi diri sendiri, 4) mengenali emosi orang lain (empati), dan 5) kecakapan dalam membina hubungan baik dengan orang lain (Goleman, 1995).

\section{METODE}

Rancangan penelitian eksperimen yang digunakan adalah jenis True Experimental Pre-test, post-test Control Group Design. Penggunaan jenis eksperimen ini karena peneliti 


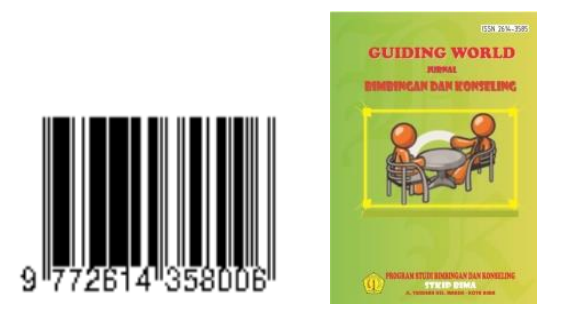

menggunakan subjek penelitian dalam bentuk kelompok eksperimen dan kelompok kontrol yang dipilih secara random. Peneliti ingin menguji ada tidaknya pengaruh treatment yang diberikan dengan model experiential learning untuk mengajarkan keterampilan mengelola emosi marah dan menguji keefektivitasan treatment yang diberikan dari hasil perbandingan pre-test dan post-test.

Rancangan "pre-test, post-test Control Group Design" dapat dilihat pada gambar 1

\begin{tabular}{llll}
$\mathrm{R} 1$ & $\mathrm{O} 1$ & $\mathrm{X}$ & $\mathrm{O} 2$ \\
\hline $\mathrm{R} 2$ & $\mathrm{O} 3$ & & $\mathrm{O} 4$
\end{tabular}

Gambar 1 Desain Eksperimen pre-test, post-test Control Group Design (Tuckman, 1999).

R1: Penempatan Subjek (kelompok) eksperimen secara random

O1: Pengukuran pertama (pre-test) pada kelompok eksperimen sebelum diberikan perlakuan

Gambar 1 menunjukkan bahwa penempatan subjek penelitian dalam kelompok eksperimen dan kelompok kontrol dipilih secara random dan diberikan pre-test. Kegiatan selanjutnya adalah pemberian treatment dengan model experiential learning bisa untuk mengajarkan keterampilan mengelola emosi marah pada kelompok eksperimen, sedangkan pada kelompok kontrol diberikan perlakuan berupa bimbingan. Setelah diberikan treatment pada kelompok eksperimen, post-test diberikan untuk mengukur keterampilan mengelola emosi marah pada kelompok eksperimen dan kelompok kontrol.

\section{Populasi, Sampel, dan Lokasi Penelitian}

Populasi dalam penelitian ini adalah peserta didik kelas VII Tahun Ajaran 20015/2016. Pemilihan populasi ini didasarkan atas asumsi bahwa kelas VII masih transisi dari jenjang sekolah dasar ke jenjang menengah tingkat pertama SMP, yang masih beradaptasi dengan lingkungan sekolah yang baru.

Proses pengambilan sampel dalam penelitian ini menggunakan teknik purposive sampling, yaitu teknik pengambilan sampel bertujuan. Teknik ini digunakan untuk mengambil sampel melalui 1) hasil observasi dan catatan empat guru bidang studi mata pelajaran, yaitu Kimia, Sejarah, Bahasa Inggris, dan Kesenian.

Berdasarkan hasil pengukuran dengan menggunakan pencatatan hasil talis yang diperoleh guru, dan peneliti dengan menggunakan lembar observasi dari 4 guru bidang studi, diperoleh 10 sampel sebagai subyek penelitian, Sampel dalam penelitian ini adalah peserta didik SMP kelas VII yang memiliki emosi marah.

Adapun cara penetapan subjek penelitian ini adalah sebagai berikut: peneliti meminta bantuan guru bidang studi untuk mengamati peserta didik yang memiliki emosi marah.Dengan menunjukan perilaku antara lain: (1) bermain HP pada saat pelajaran, (2) berbicara/ngobrol dengan teman ketika pelajaran berlangsung, (3) mengabaikan perintah guru, (4) menggoda teman ketika pelajaran berlangsung. Peneliti mendapatkan subyek penelitian yang terdiri dari empat peserta didik yang didasarkan hasil wawancara dengan guru, dan observasi dilaksanakan ketika pembelajaran berlangsung, 4 sampel tersebut 


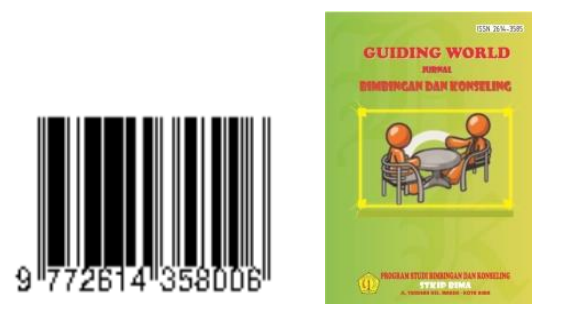

diperoleh dengan berdasarkan perolehan talis yang tinggi dan hasil rekomendasi guru berdasarkan pengamatan.

Berdasarkan hasil analisis data diperoleh kesimpulan, bahwa sampel penelitian ini ditetapkan sebanyak lima orang sebagai kelompok ekperime (AR, KK, DY, WK. dan AW) dan lima orang kelompok kontrol (SA, RS, DD, KL dan AA).

\section{Prosedur Penelitian}

Data yang dipaparkan dalam pembahasan ini meliputi kegiatan yang dilaksanakan pada tahap awal/sebelum diberikan perlakuan berupa data pretest keseluruhan, data pretest kelompok eksperimen, data pretest kelompok kontrol, tahap pelaksanaan berupa kegiatan pada proses intervensi berlangsung, dan tahap akhir/setelah diberikan perlakuan berupa data posttest baik dari kelompok eksperimen maupun kelompok kontrol.

\section{Data Pretest Keseluruhan}

Data pretest merupakan data awal yang digunakan untuk menjaring peserta didik-peserta didik yang akan mengikuti proses intervensi dan sebagai skor awal peserta didik sebelum intervensi/perlakuan diberikan kepada peserta didik. Jumlah keseluruhan peserta didik yaitu 32 peserta didik, 22 peserta didik masuk dalam kategori memiliki keterampilan mengelola emosi marah tinggi dan ada 10 peserta didik yang termasuk dalam kategori memiliki keterampilan mengelola emosi marah rendah. Data skor awal keterampilan mengelola emosi marah peserta didik SMP Negeri 6 Kota Bima dapat dilihat pada tabel 2.

Tabel 2 Skor Keterampilan Mengelola msi Marah

\begin{tabular}{ccc}
\hline Interval & Frekuensi & Kategori \\
\hline $36<$ Skor $\leq 48$ & 22 & Tinggi \\
$24 \leq$ Skor $\leq 35$ & 10 & Rendah \\
\hline Total & 42 & \\
\hline
\end{tabular}

Selanjutnya, 10 peserta didik yang masuk dalam kategori rendah dibagi menjadi dua kelompok yaitu kelompok eksperimen dan kelompok kontrol, dan diberikan perlakuan untuk meningkatkan keterampilan mengelola emosi marah.

\section{Pelaksanaan Intervensi Kelompok Eksperimen}

Proses intervensi dilaksanakan pada bulan Oktober-November pada hari senin, rabu, kamis, dan jumat selama delapan kali sesi. Kegiatan yang dilakukan dibagi menjadi tiga, yaitu tahap awal/pra intervensi, tahap intervensi, dan tahap akhir/penutup.

Strategi yang digunakan untuk peserta pelatihan keterampilan mengelola emosi menggunakan panduan experiential learning atau belajar berbasis pengalaman hasil pengembangan Gunawan (2013) yang meliputi empat tahapan yaitu: 1) concrete experience (emotions), 2) reflective observation (watching), 3) abstract conceptualization (thinking) dan 4) active experimentation (doing). Adapun penjelasan singkatnya adalah sebagai berikut:

1) Concrete experience (emotions)

Tahap concrete experience atau tahap pengalaman nyata dilaksanakan dengan 

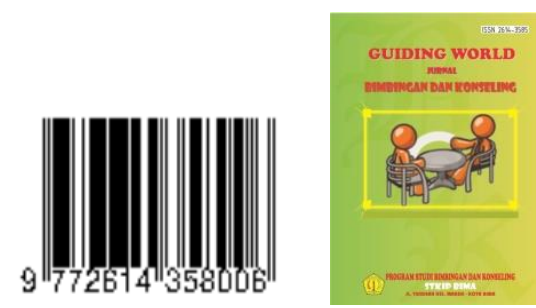

DOI: 1033627

Volume 03, Nomor 01

Mei 2020

E-ISSN: 2614-3585

mengajak peserta pelatihan mengalami emosi marah pada saat pelatihan. Situasi diciptakan melalui permainan sendok kelereng dan peserta pelatihan yang melakukan permainan tersebut mendapatkan gangguan atau godaan dari ketua kelompok (konselor) atau orang yang telah disuruh untuk memecahkan konsentrasi setiap peserta pelatihan sampai mereka merasa jengkel dan akhirnya marah. Cara yang digunakan adalah dengan mengejek atau mengadu domba antara teman yang satu dengan yang lainnya. Setelah peserta pelatihan mengalami emosi marah lalu ketua kelompok (konselor) mengajak peserta pelatihan untuk melakukan relaksasi pernafasan agar lebih tenang sehingga dapat melanjutkan kegiatan pelatihan ketahap reflective observation (watching).

2) Reflective observation (watching)

Tahap reflective observation atau tahap observasi refleksi didapatkan melalui kegiatan observasi yang dilakukan peserta didik terhadap emosi marah yang mereka alami pada saat pelatihan dan mengidentifikasi penyebab terjadinya emosi.

3) Abstract conceptualization (thinking)

Tahap abstract conceptualization atau tahap konseptualisasi abstrak merupakan tahapan untuk memahami emosi-emosi yang telah direfleksikan. Melalui pemahaman tersebut peserta diharapkan mempunyai konsep baru yang dapat diterapkan bila menghadapi emosi marah dalam kehidupan nyata. Konsep baru tersebut berupa keterampilan mengelola emosi marah dengan merubah pikiran negatif menjadi pikiran positif, kemudian diimplementasikan dalam pengelolaan emosi dan tingkah laku yang positif.

4) Active experimentation (doing)

Tahap active experimentation atau tahap eksperimentasi aktif merupakan tahap pemberian kesempatan kepada peserta pelatihan agar menerapkan pemahaman materi yang diperoleh pada pelatihan keterampilan mengelola emosi marah untuk diterapkan pada situasi yang sesungguhnya. Peserta pelatihan diberi tugas mencatat situasi yang dialami pada saat mengalami emosi marah dengan menuliskanya pada format-format yang sudah disediakan.

\section{Instrumen Penelitian}

Data dihimpun dalam penelitian ini adalah pengelolaan emosi marah, dan satuan datanya berupa frekuensi dan durasi. Selaras dengan jenis data, maka dalam penelitian ini digunakan metode observasi dengan menggunakaninstrument pedoman observasi. Untuk menghimpun data frekuensi peneliti mencatat setiap kali pengelolaan emosi marah muncul pada pedoman observasi.

Untuk melakukan pengukuran sesudah intervensi, peneliti mengembangkan sendiri instrument yang dikembangkan adalah berupa lembar refleksi diri untuk peserta didik yang dipergunakan untuk mengukur subyek penelitan sesudah dilakukan treatmen konseling kelompok dengan model experiential learning. Dalam penelitian ini data yang dibutuhkan diperoleh dengan cara:

1) Observasi, subjek peneliti oleh konselor/peneliti format observasi ini berguna untuk mengetahui perubahan perilaku subyek penelitian.

2) Memberikan Cheklist/Monitoring peserta didik untuk mengukur frekuensi dan intensitas dari emosi marah serta untuk memantau atau memonitor perubahan emosi marah. Self monitoring ini bertujuan untuk melihat perubahan perilaku peserta didik. 


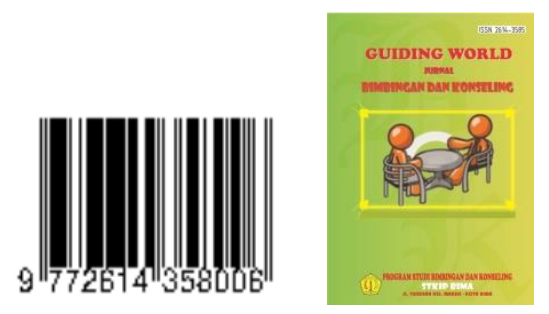

\section{Analisa Data}

Berdasarkan hipotesis dan rancangan penelitian yang diajukan, maka data yang terkumpul dalam penelitian dianalisis dengan menggunakan statistik non parametrik yaitu uji dua sampel bebas (Two Independent Sample Test Mann Whitney U). Uji ini digunakan dengan alasan bahwa uji ini merupakan uji yang digunakan untuk mengetahui ada atau tidaknya perbedaan dari dua himpunan data yang berasal dari sampel yang bebas dengan bentuk data ordinal dan memiliki sampel dibawah 30 .

Pengujian hipotesis dasar pengambilan keputusan adalah dengan melihat angka probabilitas memiliki ketentuan untuk menolak/tidak menolak $\mathrm{H}_{0}$ berdasarkan Probabilitas dengan $\alpha=0,05$, adalah sebagai berikut: jika Probabilitas $\geq \alpha$ maka $\mathrm{H}_{0}$ diterima dan sebaliknya jika probabilitas $\leq \alpha$ maka $\mathrm{H}_{0}$ ditolak. Dalam program SPSS digunakan istilah significance (yang disingkat sig.) untuk Probabilitas, atau dengan kata lain Probabilitas =sig. (Santoso, 2001). Sedangkan interpretasi hasil penelitian digunakan kriteria bahwa tingkahlakudinyatakan berhasil jika perilaku pengelolaan emosi marah peserta didik tereduksi dan tidak kurang dari (Goodwin50\% (Goodwin \& Coates, 1976).

\section{HASIL DAN PEMBAHASAN}

Hasil pelatihan dalam terapi menunjukan bahwa model experincial learning bisa untuk melatih peserta didik agar memilik keterampilan dalam mengelola emosi marah. Hal ini dibuktikan dengan persentase sebagai berikut:

Tabel 3 Skala Konversi Absolut

\begin{tabular}{ccc}
\hline Interval & Frekuensi & Tingkat \\
\hline Skor $\leq 48$ & 32 & Tinggi \\
$24 \leq$ Skor $\leq 35$ & 10 & Rendah \\
\hline Total & 42 & \\
\hline
\end{tabular}

Tabel 4 Pembagian Kelompok Eksperimen dan Kelompok Kontrol

\begin{tabular}{ccccc}
\hline & \multicolumn{2}{c}{ Kelompok Eksperimen } & \multicolumn{2}{c}{ Kelompok Kontrol } \\
\cline { 2 - 5 } No & Nama & Skor Pretest & Nama & Skor Pretest \\
\cline { 2 - 5 } 1 & AR & 30 & SA & 31 \\
2 & KK & 30 & RS & 31 \\
3 & DY & 30 & DD & 30 \\
4 & WK & 27 & KL & 28 \\
5 & AW & 25 & AA & 24 \\
\hline
\end{tabular}

Pembagian kelompok dilakukan secara random/acak. Menjaga validitas internal dilakukan dengan meminimalisir interaksi antara peserta didik kelompok kontrol dan kelompok eksperimen. Hal ini dilakukan dengan menjadwal pelaksanaan intervensi secara bergantian dan meminta guru menempatkan pada kursi yang berjarak antara masing-masing peserta didik yang menjadi subjek penelitian.

Tabel 5 Data Pretest - Posttest Kelompok Eksperimen dan Kelompok Kontrol

\begin{tabular}{cccccc}
\hline Nama Peserta didik & \multicolumn{2}{c}{ Pretest } & \multicolumn{2}{c}{ Posttest } \\
$\mathbf{1}$ & $\mathbf{2}$ & $\mathbf{1}$ & $\mathbf{2}$ & $\mathbf{1}$ & $\mathbf{2}$ \\
\hline \multicolumn{4}{c}{42}
\end{tabular}



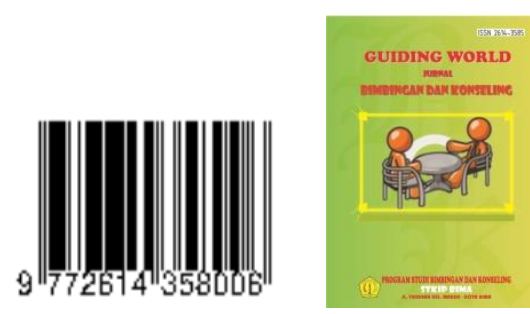

GUIDING WORLD JURNAL

BIMBINGAN DAN KONSELING

Volume 03, Nomor 01

Mei 2020

E-ISSN: 2614-3585

DOI: 1033627

\begin{tabular}{|c|c|c|c|c|c|}
\hline AR & SA & 30 & 31 & 44 & 35 \\
\hline KK & $\mathrm{RS}$ & 30 & 31 & 43 & 36 \\
\hline DY & DD & 30 & 30 & 46 & 37 \\
\hline WK & KL & 27 & 28 & 39 & 34 \\
\hline $\mathrm{AW}$ & AA & 25 & 24 & 37 & 30 \\
\hline \multicolumn{2}{|l|}{ Total } & 142 & 144 & 209 & 172 \\
\hline \multicolumn{2}{|c|}{ Mean } & 28,4 & 28,8 & 41,8 & 34,4 \\
\hline
\end{tabular}

Keterangan:

1. Kelompok Eksperimen

2. Kelompok Kontrol

Berdasarkan data pre test-post test selanjutnya data diuji dengan Two Independent Sample Test Mann Whitney $U$ dengan program SPSS versi 20.00. Analisis yang dilakukan meliputi analisis statistik pretest dan analisis statistik po

\section{PENUTUP}

Penelitian ini disimpulkan bahwa model experiential learning efektif digunakan untuk melatih keterampilan mengelola emosi marah pada peserta didik SMP Negeri 6 Kota Bima. Keberhasilan dalam pelaksanaan pelatihan keterampilan mengelola emosi dengan model experiential learning, ditentukan oleh beberapa faktor seperti: kondisi emosi peserta didik yang dilatih, pelatihnya konslor sekolah, serta situasi dan kondisi saat pelatihan dilaksanakan. Sebagaimana yang dikemukakan Calhoun \& Accocella (1995), faktor-faktor yang mempengaruhi proses pengembangan perilaku manusia adalah diri dan lingkungan. Lingkungan dapat berupa konselor, teman sebaya, keluarga. Tahapan-tahapan dalam experiential learning yakni tahap concrete experience, tahap concrete experience, tahap reflective observation (watching).

\section{DAFTAR PUSTAKA}

ABKIN.2007. Penataan Pendidikan Profesional Konselor dan Layanan Bimbingan dan Konseling Dalam Jalur Pendidikan Formal. Jakarta: Depdiknas.

Bryant, T. 2008. Self-Discipline in 10 Days "How to Go From Thinking to Do".

Washington: Human Understanding and Behaviour Publishing.

Calhoun, J.F \& Acocella, J.R. 1995, (Satmoko, R.S.)Psikologi tentang Penyesuaian dan Hubungan Kemanusiaan. Semarang: IKIP Semarang Press.

Nurhayati. 2014. Pengembangan Teknik Bimbingan Mendongeng Untuk Meningkatkan Disiplin Diri (Self-Discipline) Peseta Didik Taman Kanakkanak. Malang: Universitas Negeri Malang, Tesis tidak diterbitkan

Creswell, J. 2012. Educational Reaserch planning, Conducting and Evaluating Quantitative and Qualitative Research. New York: University Of Nebraska Lincoln Pearson.

Feist, J. \& Feist, G.J. 2006.Theories of Personality. New York: McGraw Hill. 


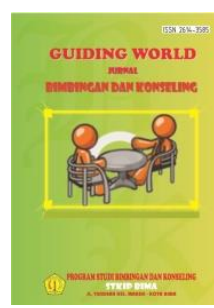

DOI: 1033627

Volume 03, Nomor 01

Mei 2020

E-ISSN: 2614-3585

Shochib, M. 1998. PolaAsuh OrangTua: Dalam Membentuk Anak Disiplin Diri. Jakarta: Rineka Cipta.

Ekman, P. 2003. Emotions Revealed: Recognizing Faces and Feeling to Improve Comunication Andemotional Life $1^{\text {st }} e d$. New York: Time Books Henry Holt and Company LLC.

Fatimah, E. 2010.Psikologi Perkembangan (Perkembangan Peserta Didik). Bandung: CV. Pustakasetia.

Goleman, D. 1995. Emotional Intelegensi. London: Bloomsbury Publishing Plc.

Hein, S. 2004. Emotional Awarness. Hat Yai, Thailand. (Online), (http://eqi.org/aware.htm.), diakses 13 Maret 2013.

Kolb, D.A. 1984. Experiential Learning. Englewood Cliffs, NJ: Prentice Hall.

Mayer, J.D., \& Salovey, P. 2000. Emotional Intellegence and The Construction and Regulation of Feelings. Applied and Preventive. (4) 1979 - 208. (Online) (http://www.eqi.org), diakses 9 Maret 2013.

Mayer, J.D., \& Cobb, C.D. 2000. Educational Policy on Emotional Intellegence: Does It Make Sense? Educational Psychology Review, (2) 163 - 183, (Online), (http://www.yale.edu), diakses 13 Maret 2013.

Santoso, S. 2001. Buku Latihan SPSS Statistik Non Parametrik. Jakarta: Gramedia.

Shochib, M. 1998. PolaAsuh OrangTua: Dalam Membentuk Anak Disiplin Diri. Jakarta: Rineka Cipta.

Stephan, A. 2012.Emotions, Existential Feelings, and their Regulation.Institute of Cognitive Science, University of Osnabrück, Germany. DOI: 10. 1177/17.Journal.(Online), (http://Online.Sagepub.com), diakses 25 September 2012 